Original Research

\title{
The Association of Pornographic Media Exposure and Nutritional Status with Early Menarche
}

\section{Deswita Deswita, Randy Refnandes and Mella Gustriyani Putri}

Faculty of Nursing, Universitas Andalas, Sumatera Barat, Indonesia

\begin{abstract}
Introduction: The adolescent menarche period has shifted to a younger age because of several factors, including a girl's nutritional status and exposure to pornographic media. The purpose of this study is to determine the relationship between pornographic media exposure and nutritional status with the age of menarche in girls in elementary school.

Methods: This research used a descriptive cross-sectional design. 121 respondents were selected by proportional random sampling. Nutritional status data was collected by measuring body mass index, while the usage of media exposure and the age of menarche were both identified using questionnaires. All data was analysed using the chi-square test.
\end{abstract}

Results: There was a significant relationship between the age of menarche with the exposure to mass media $(\mathrm{p}=0.000)$ and nutritional status $(\mathrm{p}=0.000)$.

Conclusion: The age of menarche in adolescent girls is associated with nutritional status and media exposure.

\section{ARTICLE HISTORY}

Received: February 9, 2018 Accepted: December 19, 2018

\section{KEYWORDS}

age of menarche; pornographic media exposure; nutritional status

\section{CONTACT}

Deswita Deswita $\triangle$ deswita@nrs.unand.ac.id $\equiv$ Faculty of Nursing, Universitas Andalas, Sumatera Barat, Indonesia

Cite this as: Deswita, D., Refnandes, R., \& Putri, MG. (2018). The Association of Pornographic Media Exposure and Nutritional Status with Early Menarche. Jurnal Ners, 13(2), 190-193. doi:http://dx.doi.org/10.20473/jn.v13i2.3582

\section{INTRODUCTION}

Proverawati \& Misaroh (2009) defines menarche as the beginning stage of menstruation in a girl experiencing puberty, indicating that the child has entered the stage of sexual organ maturity in her body. In the last 100 years, the age of menarche has shifted to a younger age. Aryal (2005) stated that a hundred years ago, the age of girls in Nepal who experienced menarche ranged from 15 to 19 years. Nowadays, most girls experience menarche between the ages of 10 and 16 . On average, the age is 12.5 years old (Heys et al., 2007).

The average age to experience menarche in the UK, according to Proverawati \& Misaroh (2009), is at 13.1 years old. Meanwhile, the average age to experience menarche in France is lower, at 12.8 years old (de La Rochebrochard, 2000). Several studies have shown this. This has decreased from an average age of 14 years old due to girls experiencing earlier development (Silva, 2005).

However, over the last 20 years in Moscow, the age of menarche has risen from 12.5 years old to 13 years old. This is especially the case for those weighing less than normal and with those who are more active (Kabir, Torkan, \& Hakemi, 2007). In
Indonesia, this emerging trend of the age of menarche dropping is continued. A 2010 Indonesian Health Survey concluded that the average age of menarche in Indonesian girls is at 13 years old (Riskesdas, 2010). Several studies have shown the decrease in the age of menarche in Indonesian girls. The average age of menarche has decreased from 13 years to 10 years in 2009 (Talma et al., 2013; Wulandari \& Ungsianik, 2013). The study was conducted on elementary school and junior high students in East Jakarta and it proposed that menarche had already occurred at 12.3 years of age. Putra, Ermawati, \& Amir (2016) conducted a study at a junior high school in Padang, and showed that the age of menarche has decreased from 9 years old to 15 years old.

Experiencing menarche at an early age will affected the physical development of adolescent girls and could cause non-communicable diseases. Studies show that early puberty (as measured by age of menarche) may increase the risk of breast cancer. According to UNICEF (2011) menarche at earlier stage will form the start of an adolescent girl's sexual exploration. Girls will begin to find interest in the opposite sex, which beforehand was not the case. An earlier menarche will also increase the chances of 
endometrial hyperplasia, uterine cancer and breast cancer, as this stage of life is related to progressive oestrogen-dominated hormonal issues (Al-Agha, Alabbad, Tatwany, \& Aljahdali, 2015). It could also cause certain psychological and emotional problems such as anxiety, fear and depression (Kabir et al., 2007). In a study of depressive symptoms among primary school students, there was a large discrepancy in results between girls who reached menarche at early age and boys (Trépanier et al., 2013).

Experiencing an early menarche is related to both endogenous and exogenous factors. According to Soetjiningsih (2004) the decrease in the age of menarche is associated with the nutritional status of adolescents, and according to Manuaba (2012) it is associated with the exposure of sensory stimulating information in mass media, TV and other sources. There are several research studies that have been conducted to investigate the correlation between nutritional status and an early menarche in adolescent girls (Susanti \& Sunarto, 2012). These studies have proved there are significant links (Wulandari \& Ungsianik, 2013).

There is limited evidence that has proved that pornographic media exposure may be related to a trend in earlier menarche. The progressive improvement of technology has risen impacts on most human aspects. One study conducted amongst junior high school students showed there was no significant relationship amongst the two variables (Dwi Kisswardhani, 2014), but the study focused on junior high students, not adolescents, and also didn't specify pornographic media. Based on the description above, a focus on how media exposure containing adult, vulgar or indulgent content affects menarche at an earlier age needs to occur. Currently, the government handles public health and protection by providing programmes that tackle reproductive health issues. These programmes include counselling that aims to fulfil the reproductive rights of adolescents (BKKBN, 2012).

The purpose of this study was to identify the correlation between pornographic media exposure and nutritional status with age of menarche.

\section{MATERIALS AND METHODS}

The design of study used a descriptive analytic method by using a cross sectional method approach. This study observed both independent and dependent variables, measured simultaneously. The population of the study was all of the female students at grade IV, V and VI in a public school in Padang. The sample size was 174 girls. The sampling method used a proportional random sampling technique. A stadiometer was used to measure the height of the students, and a scale to measure each girl's weight. The data was processed by the Body Mass Index (BMI) calculation to thus obtain the nutritional status data. In regard to the age of menarche and pornographic media exposure, the data was obtained using questionnaires consisting of 19 questions. Data has been analysed by using the chi-square test.

The confidentiality of the students was protected by the use of a de-identified database that did not contain any student identifying information. All data in the de-identified database was kept confidential and stored on secure servers that could only be accessed from password protected computers. Ethical approval for the study was received from the Ethics Committee of Universitas Andalas on the10th July 2015 with certificate number 245/KEPK/2015.

\section{RESULTS}

Table 1 shows that the highest group size contained girls that were 10 years of age $(35.5 \%)$. Less than half of respondents have experienced menarche $(43.0 \%)$, and some experienced early menarche $(24.8 \%)$. The table illustrates that less than half of respondents had been exposed to pornographic media (57.9\%). More than half of respondents had a normal nutrition status $(63.6 \%)$, and $30.6 \%$ of girls were overweight. Table 2 shows that the chi-square analysis results obtained the $\mathrm{p}$-value $=0.000$. This result indicates that there is a significant relationship between pornographic media exposure and the age of menarche in a student. Table 3 shows that the chi-square analysis results obtained the $p$ value $=0.000$. This indicates that there is a significant correlation between nutritional status and the age of menarche of students. Students who have a good nutritional status will experience menarche at an expected age, and those adolescents who have nutritional problems may experience it at an age not regarded as usual.

\section{DISCUSSION}

The results identified a significant relationship between an exposure to pornographic media with the age of menarche in adolescent girls. The results of this study are in accordance with a statement, which said the cause of early menstruation can also

Table 1. Demographic Characteristics of the Respondents ( $\mathrm{n}=121)$

\begin{tabular}{lcc}
\hline \multicolumn{1}{c}{ Variables } & f & \% \\
\hline Age & & \\
8 & 5 & 4.1 \\
9 & 33 & 27.3 \\
10 & 43 & 35.5 \\
11 & 33 & 27.3 \\
12 & 7 & 5.8 \\
Age of Menarche & & \\
$\quad$ Early & 30 & 24.8 \\
$\quad$ Normal & 22 & 18.2 \\
$\quad$ Late/Non-Menarche & 69 & 57.0 \\
Pornographic Media Exposure & & \\
$\quad$ Exposed & 51 & 42.1 \\
$\quad$ Not exposed & 70 & 57.9 \\
Nutritional Status & & \\
$\quad$ Low & 7 & 5.8 \\
$\quad$ Normal & 77 & 63.6 \\
$\quad$ Overweight & 37 & 30.6 \\
\hline
\end{tabular}


Table 2. Relationship between Pornographic Media Exposure and Age of Menarche

\begin{tabular}{|c|c|c|c|c|c|c|c|c|c|}
\hline \multirow{3}{*}{$\begin{array}{c}\text { Pornographic Media } \\
\text { Exposure }\end{array}$} & \multicolumn{6}{|c|}{ Age of Menarche } & \multirow{2}{*}{\multicolumn{2}{|c|}{ Total }} & \multirow{3}{*}{ P Value } \\
\hline & \multicolumn{2}{|c|}{ Early } & \multicolumn{2}{|c|}{ Normal } & \multicolumn{2}{|c|}{ Not Menarche } & & & \\
\hline & f & $\%$ & f & $\%$ & $\mathbf{f}$ & $\%$ & f & $\%$ & \\
\hline Exposed & 19 & 37.3 & 17 & 33.3 & 15 & 29.4 & 51 & 100 & 0.000 \\
\hline Not Exposed & 11 & 15.7 & 5 & 7.1 & 54 & 77.1 & 70 & 100 & \\
\hline Total & 30 & 24.8 & 22 & 18.2 & 69 & $\mathbf{5 7 . 0}$ & 121 & 100 & \\
\hline
\end{tabular}

Table 3. Correlation between Nutritional Status (BMI) and the Age of Menarche

\begin{tabular}{|c|c|c|c|c|c|c|c|c|c|}
\hline \multirow{3}{*}{$\begin{array}{l}\text { Nutritional Status } \\
\text { (BMI) }\end{array}$} & \multicolumn{6}{|c|}{ Age of Menarche } & \multirow{2}{*}{\multicolumn{2}{|c|}{ Total }} & \multirow{3}{*}{$\begin{array}{c}P \\
\text { Value }\end{array}$} \\
\hline & \multicolumn{2}{|c|}{ Early } & \multicolumn{2}{|c|}{ Normal } & \multicolumn{2}{|c|}{ Not Menarche } & & & \\
\hline & $\mathbf{f}$ & $\%$ & $\mathbf{f}$ & $\%$ & $\mathbf{f}$ & $\%$ & $\mathbf{f}$ & $\%$ & \\
\hline Low & 1 & 14.3 & 4 & 57.1 & 2 & 28.6 & 7 & 100 & 0.000 \\
\hline Normal & 5 & 6.5 & 56 & 72.7 & 16 & 20.8 & 77 & 100 & \\
\hline Overweight & 24 & 64.9 & 9 & 24.3 & 4 & 10.8 & 37 & 100 & \\
\hline Total & 30 & 24.8 & 69 & 57 & 22 & 18.2 & 121 & 100 & \\
\hline
\end{tabular}

be affected either by the conversation or visual stimuli (TV, movies or internet) of material that can be considered adult or vulgar (Proverawati \& Misaroh, 2009). The stimulation of the ears and eyes subsequently stimulates the reproductive and genital systems to accelerate genital maturation. The study conducted by Buzney \& DeCaro (2012) also found psychosocial factors affected the age of menarche, which included access to westernised content. In an earlier study, it was stated that the linkage between pornographic media exposure accelerated puberty in adolescents which then indirectly leads to an earlier age of menarche (Ayuningtyas, 2013). In this study, the survey explained that the media provide most of the information containing sexual imagery, and also proved that adolescents often have easy access to prohibited content. This social factor contributed to the rapid growth of adolescent girls, decreasing the age of menarche and potentially allowing risky physical development.

The results also identified a significant relationship between nutritional status and the age of menarche. In recent study of obese adolescent girls, it was found that the nutritional status could lead to an earlier menarche (Lusiana \& Dwiriani, 2007). Nutrition also affects sexual maturity in girls who have experienced their first menstruation earlier than average. These girls tend to experience more severe and frequent periods compared with those who have not menstruated at the same age. In contrast, adolescent girls whose experience menarche later weight less than adolescent girls menstruating at a normal age, irrespective of height. In general, in girls of a same age, those menstruating earlier will have a higher body mass index (BMI), and those menstruating later will have a smaller score BMI (Soetjiningsih, 2004). Excessive nutritional fulfilment brings adolescent girls to experience biological hormonal changes earlier, and this could also cause an acceleration of sexual maturation development.

Bogin (2011) stated that menarche does tend to occur earlier in adolescent girls around 20 to 30 percent above the ideal body weight, and later in adolescent girls with malnutrition. The leptin protein hormone is a form of a fat cell that plays a major role in the metabolism mechanism. It is secreted by the fat cells that have the primary function of controlling body fat and weight tissue. Leptin then triggers the release of the follicle stimulation hormone (FSH) and luteinising hormone ( $\mathrm{LH}$ ) in the ovaries, resulting in follicular maturation and oestrogen formation. Oestrogen causes negative feedback against FSH, resulting in the reduction of FSH production. The decrease in FSH levels causes late follicular growth and impacts the decreasing of oestrogen levels. The decreasing oestrogen levels cause the proliferation of endometrial blood vessels to discontinue. Therefore, the endometrial layer undergoes desquamation, resulting in the bleeding and the intangible vagina flow known as the first menstruation (menarche). The occurrence of the first menstrual cycle in adolescent girls directly affects the ability to reproduce. In overweight adolescent girls, there is an increasing of leptin secretion which can accelerate menarche (Ong et al., 2007).

This study reveals that nutritional status and pornographic media exposure of adolescent girl students will affect the age of menarche. This study highlighted is due to nutritional factors and exposure to media with insufficient content has shifted the sexual maturity. A healthy and balanced diet providing adequate nutrition and a restriction on pornographic media exposure would improve the normal growth and developmental status of the adolescent girl, and ultimately achieve the goal of approaching menarche at the normal age.

\section{CONCLUSION}

Pornographic media exposure and nutritional status are strongly associated with an early menarche in adolescent girls. The increasing frequency of inappropriate content accessed by adolescents stimulates rapid maturation among girls, and is associated with an early menarche. Meanwhile, nutritional status also contributes to the biological growth and development of adolescent girls. Further study should be conducted to identify the appropriate strategies to respond to the early menarche phenomenon and adolescent sexual development. 


\section{REFERENCES}

Al-Agha, A. E., Alabbad, S., Tatwany, B., \& Aljahdali, A. (2015). Menarche age of mothers and daughters and correlation between them in Saudi Arabia. Reprod Syst Sex Disord, 4(3), 1000153. doi:10.4172/2161-038X.1000153.

Aryal, T. R. (2005). A Probability Model to Describe the Distribution of Age at Menarche in Nepal. Nepal Journal of Science and Technology, 6(1).

Ayuningtyas, R. (2013). Hubungan Status Gizi dengan Usia Menarche pada Siswi SMP Negeri 1 Jember. Universitas Jember [online] Available at: http://repository.unej.ac.id/bitstream/handle/1 23456789/9993/Ratih\%20Ayuningtyas\%20\%20 062310101002 1.pdf?sequence=1 (Accessed: January 22, 2019).

BKKBN, D. K. K. (2012). Survey Demografi dan Kesehatan Indonesia 2012. Jakarta: Kementrian Kesehatan Rl. [online] Available at: http://kesga.kemkes.go.id/images/pedoman/SD KI\%202012-Indonesia.pdf (Accessed: January 22, 2019).

Bogin, B. (2011). Puberty and adolescence: An evolutionary perspective. Encyclopedia of Adolescence, vol. 1, pp. 275-286. DOI: 10.1016/6978-0-12-373915-5-000033-4.

Buzney, C. D., \& DeCaro, J. A. (2012). Explanatory models of female pubertal timing: discordances between cultural models of maturation and the recollection and interpretation of personal developmental experiences. Culture, Medicine, and Psychiatry, 36(4), 601-620. doi: 10.1007/s11013-012-9277-8.

de La Rochebrochard, E. (2000). Age at puberty of girls and boys in France: Measurements from a survey on adolescent sexuality. Population: An English Selection, 51-79.

Dwi Kisswardhani, A. (2014). Hubungan Antara Status Gizi, Tingkat Paparan Media Massa dan Faktor Keturunan dengan Usia Menarche pada Siswi Di SMP Negeri 1 Subah Kabupaten Batang. DISS, Universitas Muhammadiyah Surakarta.

Heys, M., Schooling, C. M., Jiang, C., Cowling, B. J., Lao, X., Zhang, W., ... Lam, T. H. (2007). Age of menarche and the metabolic syndrome in China. Epidemiology, Vol. 18, No. 6, 740-746.

Kabir, A., Torkan, F., \& Hakemi, L. (2007). Evaluation of age at menarche and relevant factors in physically active Iranian girls. Int $J$ Endocrinol Metab; 2: 52-60.

Lusiana, S. A., \& Dwiriani, C. M. (2007). Age of menarche, food consumption, and nutritional status of female elementary school children in Bogor. Jurnal Gizi Dan Pangan, 2(3), 26-35. [online] Available at: http://dx.doi.org/10.25182/igp.2007.2.3.26-35. (Accessed: January 22, 2019).

Manuaba, I. B. G. (n.d.). Fajar Manuaba, IBG. 2007. Pengantar Kuliah Obstetri.
Ong, K. K., Northstone, K., Wells, J. C. K., Rubin, C., Ness, A. R., Golding, J., \& Dunger, D. B. (2007). Earlier mother's age at menarche predicts rapid infancy growth and childhood obesity. PLoS Medicine, 4(4), e132. [online] Available at: https://doi.org/10.1371/journal.pmed.0040132. (Accessed: January 22, 2019).

Proverawati, A., \& Misaroh, S. (2009). Menarche menstruasi pertama penuh makna. Yogyakarta: Nuha Medika, 25-26.

Putra, R. N. Y., Ermawati, E., \& Amir, A. (2016). Hubungan Indeks Massa Tubuh (IMT) dengan Usia Menarche pada Siswi SMP Negeri 1 Padang. Jurnal Kesehatan Andalas, 5(3). [online] Available at:

http://jurnal.fk.unand.ac.id/index.php/jka/articl e/view/575/464 (Accessed: January 22, 2019).

RISKESDAS. (2010). Riset Kesehatan Dasar (Riskesdas) 2010. Jakarta: Kemenkes RI, 50-52. [online] Available at: http://kesga.kemkes.go.id/images/pedoman/Ris kesdas\%202010\%20Nasional.pdf (Accessed: January 22, 2019).

Silva, P. D. (2005). Menarche and Lifestyle. Wisconsin Medical Journal, 104(7), 24.

Soetjiningsih, S. (2004). Tumbuh Kembang Remaja dan Permasalahannya. Sagung Seto. Jakarta, 320.

Susanti, A. V., \& Sunarto, S. (2012). Faktor Risiko Kejadian Menarche Dini pada Remaja di SMP N 30 Semarang. Journal of Nutrition College, 1(1), 125-126. [online] Available at: doi:http://dx.doi.org/10.14710/jnc.v1i1.67. (Accessed: January 22, 2019).

Talma, H., Schönbeck, Y., van Dommelen, P., Bakker, B., van Buuren, S., \& HiraSing, R. A. (2013). Trends in menarcheal age between 1955 and 2009 in the Netherlands. PloS One, 8(4), e60056. [online] Available at: https://doi.org/10.1371/journal.pone.0060056. (Accessed: January 22, 2019).

Trépanier, L., Juster, R.-P., Marin, M.-F., Plusquellec, P., Francois, N., Sindi, S., ... Andrews, J. (2013). Early menarche predicts increased depressive symptoms and cortisol levels in Quebec girls ages 11 to 13. Development and Psychopathology, 25(4pt1), 1017-1027. doi: 10.1017/S0954579413000345.

UNICEF. (2011). adolescence in Tanzania. Dar Es Salaam: United Nations Children's Fund Tanzania. [online] Available at: https://www.unicef.org/adolescence/files/TANZ ANIA ADOLESCENT REPORT Final.pdf (Accessed: January 22, 2019).

Wulandari, S., \& Ungsianik, T. (2013). Status Gizi, Aktivitas Fisik, dan Usia Menarche Remaja Putri. Jurnal Keperawatan Indonesia, 16(1), 55-59. [online] Available at: doi:https://doi.org/10.7454/jki.v16i1.20. (Accessed: January 22, 2019). 